\title{
The New L. S. U. Library in Action
}

66 TT IS THE BEST university library build-

1 ing in the country." So says a former university vice-president, president and chancellor-and one without any connection to Louisiana State University.

Now, of course, such a statement is only an expression of opinion and one that can only be justified if the word "best" is adequately defined. This definition is not my present purpose which is rather to describe the new Louisiana State University Library and to recount a little of how it got the way it is.

Any new library building requires a great deal of preliminary planning, and many questions must be raised so that specific answers can be given before a library can be built. It may be recalled that some of the questions were pointed out about two years ago as they related to L.S.U. ${ }^{1}$ They have been under consideration by all library planners in one form or another since time began.

Here are some of the answers which have been given at L.S.U.:

The new Louisiana State University Library is an air conditioned, modular, open shelf, divisional library. It is a big building-324' $\times 192^{\prime}$. The module is $27^{\prime}$ x 24'. The simple rectangular building has twelve modules in one direction and eight in the other. All of which means that each of the three floors is about an acre and a half in size, and there is a total of 186,000 square feet.

The lighting is nearly uniform throughout with a high light intensity at table height. The lighting (except for incan-

1 Sidney Butler Smith, "Dreams and a New Build. ing." CRI XVIII (1957), 132-140.

Dr. Smith is Director of Libraries, Louisiana State University. descents in the corridors and stairways) is done by fluorescent fixtures recessed into the ceiling. Each fixture is eight feet long and contains two tubes four feet long.

The library has a divisional arrangement-social science, humanities, and science. Each division has one half of a floor where the books and periodicals are arranged by Dewey Classification number and all are open shelves. Current journals are arranged alphabetically on sloping shelves with back issues of the current volume on a flat shelf below the recent issue.

Seating is provided at large four- by six-foot tables, at individual carrels, in informal occasional groups; and double carrels are provided in rows within the stacks so that no one is ever very far from a place to sit while browsing in the collections. Study enclosures-161 altogether-are provided in the divisions for assignment to faculty and graduate students who are working on projects, papers, or theses.

The location of the new L.S.U. Library, very close to most classrooms and laboratory buildings, made a centralized building possible. From a library program which formerly included a main library and nine branches, the new building allows for consolidation of the collections, with only the chemistry library remaining outside in its former quarters.

In addition to the divisions the library also contains several specialized rooms. There is a documents room for all United States and United Nations publications. Newspapers are housed in a separate room adjacent to the material in micro form where reading machines are available. (The photoduplication labora- 
tory remains in the old building.) A large listening room is provided next to nine small booths where students can come individually or in small groups to hear recorded music, speeches, or drama.

The Louisiana Collection is shelved along with rare books in a handsome cypress-panelled room on the second floor. This area is situated next to the archives department which has recently come under the administration of the library.

L.S.U. has long had a distinguished and well known library school. The school now has quarters for faculty offices, classrooms and library in the new building. Technical services are situated in a large area on the main floor adjacent to the receiving room on one side, and to the card catalog and bibliography collection on the other. Seminar and typing rooms have been provided on each floor. Rooms for group study or conferences are available. Smoking is permitted in two areas, one in the basement and one on the second floor.

The goal for the library was room enough for one million volumes and for over two thousand people all to be using it at the same time. Such an operation naturally entailed decisions on basic library services. Where, for example, would we do our reference work? In the divisions, each staffed by four full time professional staff members, supplemented by two twenty-hour trainees who are graduate students and by a number of student assistants. Reference books are in each division according to Dewey number which also determines the location of all material. What about reserve books? Shelved in the divisions on open shelves, arranged usually by course but sometimes by department. How do we circulate books? At check points at the two doors where all material going from the library is inspected and that which is library material is charged out. How many catalogs are there for such a large library? One, located on the first floor. Everyone coming to the building goes right by it. Since documents are shelved in their own room, arranged by the Superintendent of Documents classification, and do not appear in the public catalog, there is a documents catalog. Serials holdings which formerly were given in the public catalog by year are no longer available in this way. There is a serials record giving full serials information just a few feet away from the catalog.

The lobby and the adjacent open area which houses the card catalog become the central information center of the Library. Here is an information desk staffed from 8 a.m. until 10 p.m. by professional librarians. Staff members from the public services and technical services plus the administrative heads have assignments varying in length from one to four hours at this desk and are thus aware of the many kinds of questions which are asked.

What influence did the building have on the number of staff members? Three factors made it possible or necessary to begin operation in the new building with the same staff as existed last year: (1) the branch librarians could be used in the new library, thus augmenting the former main library staff; (2) budgets were such that increases were not possible; (3) we wanted to experiment and see what was needed. We may well need to request some additional staff, particularly among clerical personnel, but if we do we will have some experience to tell us where the increases should be.

The building has a warm and inviting quality about it even though the lines are contemporary and simple. Red birch plywood panelling in many rooms and corridors, and vinyl plastic floors serve as a handsome neutral background for colorful columns and brightly upholstered chairs or Naugahyde chair backs.

With the library designed so that by closing the back door control of the entire building is possible at the front 
check points, we can stay open until midnight as a study hall by having two mature student assistants on duty, one at the check points and one to be available in any part of the building.

What does this kind of a building do for student use? Naturally it is too early to tell, for the building opened on a full schedule on September 12, 1958. But in our first full calendar month of operation after that we were visited by about half the student body a day. (That is, we frequently have five thousand people come in the door-out of a ten thousand student body-though we know that some people come in several times.) And from the number of books and journals which had to be replaced on the shelves we feel that the open shelf arrangement has much to be said for it. The whole question of how the transition was made to the new building is a subject all of its own. Briefly, we prepared a four-page leaflet on the new building, a copy of which was handed to everyone on the

(Continued on page 221)

\section{Cataloging in Source Seeks Answers}

The Library of Congress, under a grant from the Council on Library Resources, Inc., is currently running an experiment in supplying cataloging information to be printed within books themselves. During the year of the experiment (July 1958-July 1959) cataloging information is appearing in over a thousand titles being published by trade, religious, government, university, and society publishers.

As part of this testing project, the Library is eager to receive as much information as possible as to the reaction on the proposal. How would libraries use this information if it were made generally available and what effect would it have on their procedures and on their organization? Some two hundred libraries of various sizes and kinds and locations have been selected for depth interviews by consultants working for LC on a consumer reaction survey, but voluntary expressions are being sought from all interested libraries. Librarians are urged to write to the address below summarizing the reactions of their professional staffs to the ideas following.

It is hoped that books carrying their own cataloging information (being cataloged in source) would help libraries and their users by (a) getting new books to users faster, (b) cutting the present high cost of cataloging, and (c) providing greater standardization in the identification of books. With these goals in mind, what would cataloging in source mean to your library? Might it: (1) affect your library's ordering procedures, book selection, reference, or bibliographical work (particularly if bibliographic publishers and all libraries used the same form of author and title entry)? (2) affect your library's methods of obtaining and preparing catalog cards? (3) simplify or complicate your library's work? (4) eliminate equipment or create need for new equipment? (5) affect inter-library relationships such as library systems, centralized or cooperative cataloging or processing, library deposits, inter-library loans, union catalogs?

For the sake of greater bibliographical standardization, would you be willing to adopt the LC form of author and title entries? Always, or with specific exceptions?

You are urged to get your opinions on record by sending them (favorable or unfavorable) to the Director of this CIS Consumer Reaction Survey: Miss Esther J. Piercy, Enoch Pratt Free Library, Baltimore 1, Maryland. 


\section{New L.S.U. Library}

(Continued from page 196)

first day of classes. The staff members in all areas were alert to the numerous questions of location which would be asked, and, identified by small plastic name tags, they were on hand to give what help was needed. From the vantage point of only a couple of months' experience we think the students and faculty found their way with remarkable ease. Naturally this was gratifying to watch.

The L.S.U. Library is big and bright, convenient and comfortable. It has a floor plan which merits study, ${ }^{2}$ and it has a plan of operation which may be of interest elsewhere. The most important thing about it, however, is not its size but the flexible, adaptable quality of its interior, and this characteristic is of use in buildings a tenth the size or three times as big.

Such a building does not just happen. It is the result of much thought on the part of many people over many months. University faculty and administration considered various library possibilities for more than a decade. In 1954 the

2 ACRL Library Building Plans Institute. "Proceed ings of the Meetings At . . Rosement College, July 3 , 1955." Edited by Walter W. Wright. Chicago: ACRL 1956. (ACRL Monograph Number 15), pp. $146-153$.
Louisiana legislature appropriated \$3,500,000 to build it. Even before that consultants, Angus Snead Macdonald and Keyes D. Metcalf, had given advice. The firm of Bodman and Murrell and Smith, known for some time as outstanding Baton Rouge architects were chosen, along with their associates, Post and Harelson, to design the building. Visits were made by architects and library and university personnel to several buildings around the country. Everything possible was done to call on expert advice, and at every stage the library was consulted and was kept informed of all decisions. At all times the library administration was able to make its wishes known-and in almost all cases its wishes became those of the architects and the university. At least the three essential groups knew each other's viewpoint and differences could be resolved or accepted.

While it cannot be assumed that Louisiana State University has perfected its library service, it is safe to say that its new library is a distinguished one which was planned with care and which by design can be altered as new needs arise or new approaches are suggested.

\section{Missouri Medical Library}

(Continued from page 209)

tive and efficient place. The effective use of color on walls, ceilings, floors, and furniture is a major factor in creating the comfortable and alive feeling in the library. The use of the collection, oral and written comments by staff, faculty, and students, and the day-to-day activities of the library staff, all emphasize the advantages of the new quarters. It is heartening to see the library become such an active part of Missouri's new Medical Center. 